\title{
ФИЛОСОФИЯ
}

DOI: https://doi.org/10.15688/lp.jvolsu.2020.2.1

UDC 291.1

LBC 86.2

\section{THEOLOGY IN A POST-SECULAR CONTEXT: ORIGINS, PROBLEMS, AND PROSPECTS}

\author{
Dmitriy R. Javorskiy \\ Volgograd State University, Volgograd, Russian Federation
}

\begin{abstract}
The article reconstructs the cultural conditions of the possibility of theology as a specific intellectual practice. The author proceeds from the understanding of the divine as non-anthropic, that is, beyond the control of man, but at the same time exerting an irresistible influence on him. In this context, the divine appears as unintelligible, which casts doubt on the project of theology as a form of cognition of the divine. However, despite this, in the ancient Greek Poleis, the divine becomes the subject of theology as a contemplative practice; it is the contemplative attitude to the deity that allows making the divine an object of cognition. A contemplative attitude to the divine has accompanied theology throughout its history. However, it is supplemented by a practical (liturgical) attitude. The secularization of Western European culture led to the separation of theology from religious practice. In modern times, there is a specific form of theology (crypto-theology) that allows thinking about the divine and its attributes, regardless of the experience of communion with God. Besides, extra-institutional theology is being formed, free from dogmatic restrictions and even a kind of amateurish theology, whose representatives did not have special, "school" training. All these transformations eventually led to the crisis of theology and the decline of its influence. At the same time, at the beginning of the XIX century, there were conditions for the emergence of a "modern theology" that responds to the challenges of secularism. In the second half of the twentieth century, the topic and problems of modern theology were also influenced by the programs of "overcoming metaphysics" (M. Heidegger) and "deconstruction" (J. Derrida). Modern theology basically positions itself as post-metaphysical and generates more or less radical projects of phenomenological theology (J.-L. Marion, J. Manoussakis) and negative theology (J. Derrida).
\end{abstract}

Key words: theology, overcoming metaphysics, God, modern theology, negative theology, phenomenological theology.

УДК 291.1

ББК 86.2

\section{ТЕОЛОГИЯ В ПОСТСЕКУЛЯРНОМ КОНТЕКСТЕ: ИСТОКИ, ПРОБЛЕМЫ И ПЕРСПЕКТИВЫ}

\author{
Дмитрий Ромуальдович Яворский \\ Волгоградский государственный университет, г. Волгоград, Российская Федерация
}

\footnotetext{
Аннотация. В статье реконструируются культурные условия возможности теологии как специфической интеллектуальной практики. Автор исходит из понимания божественного как неантропного, то есть неподконтрольного человеку, но при этом оказывающего на него непреодолимое влияние. В таком понимании божественное предстает как неинтеллигибельное, что ставит под сомнение проект теологии как формы познания божественного. Однако несмотря на это, в древнегреческих полисах божественное становится
} 
предметом теологии как созерцательной практики; именно созерцательное отношение к божеству дает возможность сделать божественное предметом познания. Созерцательное отношение к божественному сопровождает теологию на протяжении всей ее истории. Однако при этом оно восполняется практическим (литургическим) отношением. Секуляризация западноевропейской культуры привела к отрыву теологии от религиозной практики. В новое время возникает специфическая форма теологии (крипто-теологии), которая позволяет размышлять о божественном и его атрибутах безотносительно опыта богообщения. Кроме того, формируется внеинституциональная теология, свободная от догматических ограничений и даже своеобразная дилетантская теология, представители которой не имели специальной, «школьной» подготовки. Все эти трансформации привели в итоге к кризису теологии и упадку ее влияния. Вместе с тем, уже в начале XIX века созрели условия для появления «современной теологии», отвечающей на вызовы секуляризма. Во второй половине XX века на топику и проблематику современной теологии оказали влияние также программы «преодоления метафизики» (М. Хайдеггер) и «деконструкции» (Ж. Деррида). Современная теология в основном позиционирует себя как постметафизическая и генерирует более или менее радикальные проекты феноменологической теологии (Ж.-Л. Марион, Дж. Мануссакис) и негативной теологии (Ж. Деррида).

Ключевые слова: теология, преодоление метафизики, Бог, современная теология, негативная теология, феноменологическая теология.

Начиная с 2000-х годов теология последовательно вводится в российское научно-образовательное пространство в качестве самостоятельного направления подготовки и научной специальности. Эти решения вызвали волну дискуссий в интеллектуальном сообществе по поводу научного и образовательного статуса теологии. Одна сторона категорически отрицает научный характер теологии, указывая на отсутствие в ней принятых в современной науке процедур верификации и, соответственно, отказывает ей в праве участия в системе светского образования [Александров и др. web]. Другая сторона ссылается на историческую изменчивость критериев научности, на их конвенциональный характер, а также на опыт других стран, где теология сохраняет свои позиции в университетах до сих пор [Митрополит Волоколамский Иларион (Алфеев Г.В.) 2019; Снисаренко 2020]. Похоже, дискуссия не завершена, несмотря на то, что административные решения уже приняты и юридически оформлены. Повидимому, диспутанты едва ли продвинутся дальше обменов мало связанными друг с другом тезисами и безразличными аргументами, пока не будут разобраны смысловые завалы вокруг теологии, накопившиеся за время пресловутой «войны» между «наукой» и «религией». Как часто бывает в таких случаях, участники поединка редко задумываются, с чего все началось, и ради чего ломаются копья (хотя некоторые спорщики держат в поле зрения политичес- кие интересы, стоящие по ту сторону дискуссии).

Цель этой статьи - внести ясность в понимание предмета теологии, эпистемологических и социально-культурных условий ее возможности и, соответственно, перспектив в современной ситуации, которая здесь обозначена как «постсекулярная».

Концепт «постсекулярное общество» получил распространение благодаря Юргену Хабермасу, который в своем выступлении на Всемирном философском конгрессе в Стамбуле в 2003 году использовал это словосочетание, характеризуя новую ситуацию во взаимоотношениях «религиозного» и «секулярного» социальных сегментов. Коротко говоря, речь идет о том, что проект радикальной секуляризации культуры потерпел неудачу: религия не только сохранила свои позиции в частной жизни, но осталась мощным фактором общественно-политических процессов, а теологический дискурс в интеллектуальном поле современной культуры постепенно возвращается из маргинальной зоны в самый центр публичных дискуссий. Вместе с тем, речь не идет о религиозном реванше. Секуляризация во многих сферах жизни добилась необратимых последствий. Поэтому теперь «религиозникам» и «секуляристам» придется выработать новые формы взаимодействия в публичной сфере, подобно тому, как когда-то это пришлось сделать представителям разных вероисповеданий [Хабермас 2011; Узланер 2011]. Это означает, что теология оказалась в уникальной исторической ситуации, что так- 
же заставляет вновь поставить вопрос о сущностных и случайных ее характеристиках, о ее генезисе и исторической судьбе.

В собственном смысле слова теология «наука о божественном». И уже здесь может возникнуть множество вопросов как о предмете («теос»), так и о методе («логос») этой науки.

Поскольку предмет науки, в отличие от метода, как считается, существует до ее возникновения, постольку необходимо прежде всего остановиться на нем. Такая последовательность удобна еще и тем, что главный удар критиков теологии как науки направлен именно на ее предмет: если предмет постигается «только верой» и не дан эмпирически, то он не имеет отношения к научной деятельности. Однако полемика вокруг предмета теологии до сих пор вращалась в контексте несовместимых метафизик, и поэтому едва ли имела перспективу хоть как-то сдвинуться с мертвой точки. В конце концов, споры сводились к тому, что не все актуальные и потенциальные предметы сознания могут быть даны эмпирически, и наделение или отказ в наделении их экзистенциальным статусом - волевой, а не интеллектуальный акт.

Однако с феноменологической точки зрения это - преждевременная капитуляция. Если вынести за скобки априорные метафизические конструкции и взглянуть на предмет без идеологических предрассудков, то открывается та область реальности, которая традиционно описывается религиозным языком. Это - область того, что не поддается контролю со стороны человека, но при этом оказывает на него неотвратимое воздействие. Для концептуализации этой области реальности вводится оппозиция «антропное / неантропное» [Пигалев 1999, 62; Rosenstock-Huessy 1958] ${ }^{1}$. Антропное - человекоразмерное, «подручное», интеллигибельное, доступное, подконтрольное, то, чье существование имеет целью благо человека. Неантропное, напротив, - нечеловекоразмерное, чуждое, неинтеллигибельное, далекое, неподконтрольное, то, о чем нельзя сказать, что оно подчинено человеческим интересам.

В таком случае, означаемое религиозной символики (духи, боги, ангелы, демоны и т. п.) относится к области неантропного. Эти «религиозные» инстанции воспринима- ются человеком как принуждающие и не поддающиеся контролю силы. И в этом смысле они ни в коем случае не являются плодом распаленной фантазии homo religiosus. Они составляют неотъемлемую часть жизненного мира человека; причем, насколько позволяет судить культурная антропология, - необходимую часть. Даже секулярный человек сталкивается с действием таких сил и косвенно признает их наличие, несмотря на атеистические декларации. К примеру, само наличие конфликтологии в кругу социально-психологических наук свидетельствует о том, что конфликт рассматривается как процесс, который до некоторой степени не зависит от воли его участников. То есть существуют неантропные инстанции, которые как бы втягивают людей в поле своего действия. Примечательно, что в мифах эти силы также опознаются и получают имена (например, в Древней Греции они ассоциировались с Эриниями). Другое дело, наука пытается поставить эти силы под контроль, лишить их божественного статуса. Но здесь наука не открывает ничего нового: во всех известных политеистических традициях бытуют представления о возможности до некоторой степени контролировать богов, возвыситься над ними. У науки, в этом отношении, есть предшественница - магия, которая также во многих своих формах (например, в теургии) претендует на управление богами как неантропными силами.

Мифы представляют собой в таком случае не что иное, как достаточно раннюю практику описания и первичного упорядочивания представлений о неантропных силах. Разумеется, эта практика сильно отличаются от научной, так как в ее основе лежит не наблюдение, созерцание, а аффективно заряженное столкновение с конкретной неантропной инстанцией. Поэтому миф использует не рационально выверенные понятия, а эмоционально насыщенные образы. С этой точки зрения проблемным представляется само существование «науки о божественном». Отношение к богам выстраивалось скорее по модели отношений в семейной общине, где любовь, доверие или страх преобладают над расчетливостью. Миф - результат скорее травмирующего или воодушевляющего опыта, чем бесстра- 
стного наблюдения. Генезис мифоподобных образований легко наблюдать на примере исторических событий, которые впоследствии оформляются в виде нарративов, лишь по касательной связанных с так называемыми «историческими фактами». Так, представления о событиях октября 1917 года в Петрограде в коллективной памяти советских людей были сформированы скорее кинематографом или художественной литературой, чем научной инвентаризацией фактов. Некоторые из этих образов (например, «штурм Зимнего дворца» в фильме Эйзенштейна) вообще являются художественным вымыслом, но были приняты в качестве правды, по-видимому, даже участниками событий.

Из всего выше сказанного видно, насколько далеки эти представления от «логоса» и «логики». На это многократно обращали внимание противники логизации религии (Тертуллиан, Паскаль, Кьеркегор). Вместе с тем, уже в древневосточных цивилизациях предпринимаются первые попытки рационализации мифических представлений о богах, наподобие древнеегипетских жреческих школ - Гелиопольской, Мемфисской и Фиванской. Эти школы пытались упорядочить весьма разномастное и противоречивое скопище богов египетских номов [Коростовцев 2000].

По-видимому, правы те, кто связывает подобного рода «богословие» с социальнополитической практикой. Социальная редукция религиозных представлений, начатая Марксом и в деталях разработанная Дюркгеймом [Дюркгейм 2018], отнюдь не противоречит взятому здесь подходу, но прекрасно дополняет его, ведь всякое политическое событие и всякий социальный процесс содержат в себе примесь неантропного. Более того, есть основания полагать, что не природа с ее вызовами и благами, а именно социальная жизнь ставила первобытного человека лицом к лицу с непредсказуемым, непосильным, опасным и вселяющим надежды. Поэтому нет ничего удивительного в том, что первые формы рационализации мифов легко прочитываются сквозь политические линзы. В самом деле, любое политическое событие требовало своего «теологического» осмысления, а всякое политическое действие сопровождалось «богословской» декларацией. Причем жрецы (в роли политологов и политтехнологов) и их политические заказчики вовсе не были застрахованы от последствий своих ошибок. Всякая неверная интерпретация происходящего «на небесах» быстро оборачивалась провалом земных начинаний. Яркий пример тому - судьба реформы фараона Аменхотепа IV (Эхнатона): его преждевременный «монотеизм» совершенно не соответствовал тому раскладу «божественных сил», который царил в долине Нила, поэтому учрежденный Эхнатоном культ бога солнечного диска Атона остался умозрительной конструкцией, взятой из воображаемого одного человека и сравнительно небольшой группы его сторонников [Розеншток-Хюсси 2000, 224-229].

Теология как специфическая, странная форма знания могла возникнуть только в определенном культурном контексте, который сформировался в древнегреческих полисах. Само слово «теология» в своем нынешнем значении восходит к аристотелевскому неологизму - «теологика». Аристотель в одном из своих эпистемологических текстов, помещенных в шестую книгу сборника «Метафизика», разграничивает три умозрительные науки: математику, физику и теологику. При этом теологика трактуется как учение о «неподвижной сущности» [Аристотель 1976, 182].

Здесь следует обратить особое внимание на то, что теологика помещена в круг созерцательных учений. Созерцание или, по-гречески - «теория» - это особая познавательная практика, глубоко укорененная в древнегреческой культуре. «Созерцание» как форма познания характеризуется прежде всего неучастием в жизни своего предмета: созерцатель никак не воздействует на то, что созерцает; более того, созерцаемое в идеале даже не знает о том, что является предметом созерцания. С другой стороны, созерцатель не испытывает критического воздействия со стороны созерцаемого: созерцаемое проникает лишь в область сознания. Причем считается, что созерцатель контролирует все те процессы, которые происходят в его сознании. Иными словами, созерцатель не испытывает со стороны предмета созерцания какого-либо принуждения. Созерцание - свободная игра. Примечательно, что Аристотель допускает в качестве объектов созерцания богов, которые 
по определению являются силами, воздействующими на человека и, как правило, успешно сопротивляющимися воздействию с его стороны. Нечто безразличное к человеку, не оказывающее на него воздействия в этом смысле не может быть опознано как бог. Тем удивительнее выглядит то, что удалось создать грекам.

Созерцательное отношение к божественному имело в греческой культуре ко времени жизни Аристотеля глубокие корни, восходящие к Гомеру и Гесиоду. Именно эти поэты открыли для греков возможность безопасного наблюдения за богами. Гомер и Гесиод изобрели особую форму речи: речи не $\kappa$ богам, а $o$ богах [Розеншток-Хюсси 2000, 304-319; Пигалев 2001, 252-259]. Именно к Гомеру и Гесиоду восходит тот тип речи о богах, который впоследствии повел исследователей мифологических традиций по ложному пути, с которого они смогли сойти только благодаря антропологам, использовавшим включенное наблюдение и открывшим ритуально-мифологическую нерасторжимость [Малиновский 1998, 94-144]. В догреческих культурах вообще не было «мифов» в узком значении этого слова как «рассказов о богах». «Мифы» древневосточных цивилизаций, как и первобытные «мифы» - это сценарии ритуала, они вообще не существовали вне ритуального контекста. Греки отделили речь о богах от ритуала и тем самым совершили тот прорыв, который впоследствии породил «теологику».

Священный трепет (mysterium tremendum) и зачарованность (fascinans) [Отто 2008], свойственные человеку, попавшему в поле действия неантропных сил, сменились бесстрастным созерцанием. Переходной формой от ритуала к теологии стал театр. Само слово «театр» отсылает к практике созерцания - «теории» ${ }^{2}$. Театр, первоначально, - своеобразный «аквариум», куда помещаются и, тем самым, становятся предметами созерцания боги. В самом деле, театральная практика имеет в своей основе негласные правила, которые отражают как раз особенности созерцания. Никому из зрителей не придет в голову покинуть свое место во время представления и броситься на выручку главному герою, попавшему в переплет. Также никому не придет в голову в панике выбежать из зрительного зала, если на сцене появи- лись вооруженные люди, и даже если они чтото воинственное выкрикивают в направлении зрителей. Таким образом, театр выводит божественное из сферы повседневности и сферы ритуальных практик и помещает его в особый резервуар, где оно становится предметом созерцания [Розеншток-Хюсси 2000, 317 ].

Следующий шаг на пути к теологии порожденные древнегреческой культурой философские практики. Принципиально важно то, что театр и философию объединяет выключенность из повседневных практик. Философия - дочь «досуга», свободного времяпрепровождения. В греческой философии едва ли не общим местом было убеждение в том, что заниматься философией могут только те, у кого есть досуг. А досуг - это особый хронотоп, где и когда человек может почувствовать себя свободным от обязанностей, рисков и ответственности повседневной социальной жизни. Вооружившись досугом, гомеровским и гесиодовским нарративом, а также театральным опытом, древнегреческие философы обрушились на обывательскую религию греков. Уже Ксенофан из Колофона подробно указывал на неувязки в представлениях греков о богах и, прежде всего, на антропоморфизм, который явно противоречил тезису о совершенстве божественной природы. Переход из режима богообщения в режим богосозерцания дал Ксенофану возможность переосмыслить теологические воззрения и уподобить бога сфере как совершенной стереометрической фигуре, а также утверждать, что бог по самой своей природе находится в покое, что любые аналогии с движениями человеческой души (жаждой власти, любовью, завистью, ревностью и т. п.) неуместны [Фрагменты... 1989, 160]. В дальнейшем древнегреческие философы укрепляли и развивали позицию философии как контролера качества религиозных представлений. Эта тенденция достигнет кульминации уже в политической мысли Платона, который применял функциональный подход к религии и рассматривал традиционные мифы эллинов с позиции политической целесообразности: в какой мере они способствуют или препятствуют воспитанию гражданских добродетелей [Платон 1994, 149-157]. Вместе с тем, продолжалась разработка модели «философского бога». В платонизме и 
аристотелизме опробовались тринитарная и унитарная теологические концепции. Платон предлагал различать бога как материальный космос в его совокупности, бога-демиурга творца материального космоса и бога - прообраза материального космоса [Платон 1994, 433-435]. Аристотель же предлагал понимать бога как основание бытия (причина всех причин, начало всякого движения и т. д.) [Аристотель 1976, 70].

Эпоха эллинизма скорректировала траекторию теологической мысли, заданную аттической классикой. С одной стороны, многообразные религиозные традиции, с которыми греки столкнулись на Востоке, продемонстрировали небывалую гибкость и подвижность религиозного воображения. С другой стороны, изобретенная греками философия привлекла внимание религиозных мыслителей Ближнего Востока как способ мирного контакта туземной традиции с эллинистической культурной оболочкой. Особенно впечатляющие теологические результаты дал контакт философии с древнееврейским монотеизмом. Инициированный Филоном Александрийским, а затем продолженный христианскими Отцами Церкви синтез образа библейского Бога с эллинистической концепцией философского бога предопределил на несколько веков поле теологической деятельности христианских, иудейских и исламских богословов, а также заложил основы золотой эры теологии (III-VIII вв.).

Представляется, что главным интеллектуальным сражением первой половины золотой эры стала полемика между «языческими» ${ }^{3}$ и христианскими неоплатониками. «Языческие» неоплатоники (Плотин, Порфирий, Ямвлих, Прокл и др.) систематизировали многообразные религиозные представления и даже практики эллинистического мира, а также согласовали философскую теологию с религиозными традициями народов Средиземноморья [Whitteker 1918; Лосев 1988; Светлов 2000; Ведешкин 2014]. Христианские же Отцы Церкви теологически осмысливали мессианское событие жизни, смерти и воскресения Иисуса Христа в контексте философски проработанного монотеизма.

Свободная циркуляция идей в этой дискуссионной среде была нарушена вмешательством имперской власти Рима, находившейся в поисках наиболее эффективной модели социального контроля. Примеривая на политическое тело Империи различные теологические одеяния, политическая элита к концу IV в. в итоге остановилась на христианской модели теологического синтеза: начатый императором Константином Великим (первая треть IV в.) процесс христианизации имперской идеологии завершился политикой императора Феодосия (конец IV в.), запретившего на территории Римской империи поклоняться какимлибо богам, кроме единого Бога. При этом не следует связывать этот выбор только с качеством теологической работы христианских мыслителей, хотя ни эрудиции, ни диалектического искусства, ни риторического мастерства им было не занимать. Возможно, решающую роль сыграл не столько интеллектуальный, сколько социально-технологический продукт, предложенный церковной элитой - сплоченная сеть христианских общин, покрывшая почти весь средиземноморский мир и вобравшая в себя не только эллинизированную «интеллигенцию», но и множество иных социальных групп - «широкие народные массы», выражаясь вульгарно-марксистским языком.

Не менее значительной для судьбы теологии стала полемика внутри христианства, развернувшаяся на Вселенских соборах. В сущности, речь шла о степени адекватности передачи философской лексикой уникального для христиан мессианского события - события Боговоплощения, а также библейского текстуального сопровождения этого события. Таким удивительным образом созерцательная теология античной культуры наложилась на ближневосточные и эллинизированные религиозные практики. Усилиями выдающихся мыслителей своей эпохи был выявлен концептуальный потенциал философского языка, опробованы самые разные траектории богословской мысли и выработаны чеканные формулировки церковной догматики. Дальнейшая богословская работа осуществлялась в заданных рамках, а всякая богословская новация тестировалась на соответствие или несоответствие догматике. Средневековье - «серебряный век» теологии - было временем решения двух комплексов задач. Первый комплекс, поднятый западноевропейской схоластикой, был связан с попыткой рационализации дог- 
матики, наведением границ между знанием и верой. Второй комплекс, в большей мере актуальный для византийского богословия, касался согласования догматики и мистических практик, в особенности исихазма, вызвавшего обострение теологической полемики вокруг паламитства.

Заданные церковной догматикой рамки были, по крайней мере, отчасти сняты Реформацией XVI-XVII вв. Отсечение церковного Предания от Писания и лишение первого статуса богословского авторитета, проделанное протестантами, открыло двери для богословского творчества, которое первоначально затронуло периферию догматической системы вопросы соотношения заслуг человека и божественной милости, а затем стало смещаться в центр - к фигуре Бога и Его воли: может ли богослов мыслить Бога зависимым от превратностей человеческого выбора или божественная воля абсолютно суверенна, а значит свобода человека - иллюзия, по ту сторону которой открывается абсолютное божественное предопределение. Удивительным образом в богословском поле Западной Европы воскресли казалось уже давно побежденные и забытые ереси. Богословие перестало быть профессиональным занятием клириков, стало достоянием мирян ${ }^{4}$.

В университетской среде, где профессиональная теология уже давно и прочно занимала свое место, также появились интеллектуалы, не считающие себя связанными какими-либо догматическими обязательствами. Но чтобы не вступать в открытую конфронтацию с церковным истеблишментом, они высказывали теологические идеи в дисциплинарных рамках философии. Можно сказать, что в Новое время философия стала своего рода криптотеологией. Именно в этом пограничном режиме работали Декарт, Спиноза, Лейбниц и многие другие. Хотя трудно не заметить, что криптотеология Нового времени формировалась в основном в отрыве от традиционных церковных практик. В каком-то смысле созерцательный характер теологии ранее компенсировался культом и аскезой. В них Бог являл себя теологу не как объект априорного созерцания, а как апостериорный партнер по диалогу. Отрыв от литургических и аскетических практик вел либо к усилению созерцательности, либо к иным религиозным практикам, служившим эмпирической основой для теологических суждений.

Впечатляющими плодами криптотеологической среды стали пантеизм, то есть отождествление бога и сущего, а также атеизм. Последнее, разумеется, - не оговорка, ведь отрицание Бога - это тоже, по существу, богословское высказывание. Как писал Ж. Деррида, атеизм «свидетельствует о напряженнейшей жажде Бога» [Ямпольская 2011, 121]. С этой точки зрения Гегель и Фейербах - стоят на вершине альтернативной богословской мысли эпохи модерна.

Для того, чтобы перейти к характеристике положения теологии в постсекулярной ситуации, необходимо обратить внимание на то, что в эпоху модерна, то есть в период возрастающей секуляризации, «классическая» теология (теология университетов и семинарий) вполне комфортно сосуществовала с альтернативной теологией. Первая, обращая внимание на вторую, ограничивалась констатацией отличий и представлением этих отличий как улик против альтернативной теологии. В ряде случаев это даже срабатывало в политическом поле и имело негативные последствия для тех, кто позволял себе рассуждать о Боге за рамками догматов. Даже то обстоятельство, что политический истеблишмент все меньше и меньше прислушивался к экспертному мнению лицензированных теологов, ни в коем случае не подрывало позиций последних. Неудачные вылазки отнюдь не смущали защитников теологических твердынь.

Таким образом, созрели условия для возникновения «современной теологии». Слово «современная» указывает на историческую периодизацию, а эта периодизация конституируется событиями. Иными словами, современной становится та теология, которая признает существование событий, установивших «современность». В данном случае не так важно, что это за события: Просвещение, выпестовавшее «образованного человека, презирающего религию», Великая французская революция, узаконившая свободную совесть гражданина, неподвластную отныне церковным институтам, Освенцим как метонимия массового организованного насилия, само существование которого не могло быть объяс- 
нено школьной теодицеей и т. п. Современным становится теолог, который больше не может двигаться в кильватере святоотеческой мысли, не учитывая новых подводных течений и наросших за сотни лет коралловых рифов.

Если взять теологию в строгих дисциплинарных рамках, а не в духе «теологии культуры», то современной ее делает признание, как минимум, двух философских событий: кризиса метафизики и практики деконструкции ${ }^{5}$.

Текст М. Хайдеггера «Онто-тео-логическое строение метафизики» [Хайдеггер 1997], мимо которого не прошел, пожалуй, ни один заметный сегодня современный теолог, раскачивает устои теологии утверждением обусловленности философского фундамента рассуждений о Боге, а точнее «божественном». Хайдеггер показал, что классическое теологическое понимание Бога как causa sui, то есть самопричины, покоится в метафизическом навыке мышления, выработанном древнегреческими философами. Греки мыслили мир как то, у чего должны быть «причина» и «основание». Они исходили из того, что сам разум подсказывает нам ход мысли, при котором мы задаемся вопросом о причинах всего сущего, а значит, если усилим наши мыслительные способности, и о первопричине всего. В итоге формируется метафизическое понятие «высшего сущего», которое тут же было взято на вооружение теологией. Классический сюжет теологии - «доказательство бытия Бога» опирается именно на этот мыслительный алгоритм. Если мы усомнимся в существовании Бога, который дан в откровении, мы может размыслить так: у всего сущего есть причины (основания), эти причины (основания) выстраиваются в последовательные ряды, которые непременно должны иметь общий предел - первопричину (основание самого себя); именно в этой точке мы и обнаруживаем Бога.

Однако, как выяснил еще учитель Хайдеггера Гуссерль, мы вовсе не обязаны двигаться по этому пути. Более того, этот путь дискредитирован произвольностью своих пресуппозиций. Случайное принятие их делает нас адептами метафизики. Однако если мы подвергнем феноменологической редукции эту установку, то она испарится прямо у нас на глазах. Как остроумно заметил Жан-Люк Марион - один из тех современных теологов, который сделал преодоление метафизики отправной точкой своей теологической концепции, если мы постоянно задаемся вопросом «почему?» относительно всего, что нас окружает, то рано или поздно мы повстречаемся с вопросом «почему почему?» и не найдем на него вразумительного ответа [Марион 2011, 129]. Новоевропейская наука явочным порядком давно отказалась от метафизического вопрошания, то есть стала благополучно обходиться без «гипотезы о существовании Бога» (Бога в качестве первопричины или самодовлеющего основания). Теоретически эта гипотеза ни к чему не обязывает. Принципы метафизики перестают действовать на нас с логически принуждающей силой, и мы можем вообще отказаться от этого стиля мышления, что и демонстрирует феноменология, начиная с Э. Гуссерля и (не) заканчивая Ж. Делёзом. Поскольку метафизика на протяжении столетий давала язык теологии в целом и христианской догматике в частности, постольку этим двум последним грозит быть погребенными под обломками метафизики. Это ставит религиозных мыслителей перед непростым выбором: либо отказаться от теологии вообще и говорить о боге «нетеологически», либо выработать новую форму теологии, свободную от метафизики. Разумеется, при этом остается еще один выход: не обращать на все это внимание и продолжать богословствовать так, как будто бы метафизика не преодолена. Однако, «современность» теологии демонстрируется как раз вовлеченностью в проблематику постметафизического мышления, вовсе не обязательно на стороне противников метафизики.

Современной теологии в свете деконструктивистского поворота в философии приходится иметь дело с тезисом об эпистемологической зависимости теологической традиции. Иными словами, нужно что-то делать с утверждением, что все теологические высказывания (от догматов до теологуменов) зависимы от культурно-исторически локальной эпистемологии и являются плодом не только соборной духовной практики Общины, но и не вполне отрефлексированных когнитивных структур. Современная философия, в особенности, эпистемологическая ее отрасль, пошла далеко в критике различных моделей знания. 
Стало понятно, что теологическое оформление религиозного опыта монотеизма несет на себе печать когнитивных конструкций, системно связанных с процессами конфигурирования социальных отношений. Развитие экономических отношений и денежного оборота сформировало эпистемологическую модель трансцендентализма, в которой «вещи» вступают в отношения друг с другом при посредничестве Абсолюта, который выделен из сети отношений, в том смысле, что он сам не испытывает воздействия. Именно деньги как всеобщий эквивалент обмена выступают социальной парадигмой теологического монизма [Пигалев 2004]. В таком случае, неудивительно, что релятивизация материального эквивалента ценности (золота) имела в качестве побочного эффекта (или сама была побочным эффектом) секуляризацию культуры. Разумеется, в науке нет абсолютно бесспорных утверждений, и речь не идет о том, что приведенные выше эпистемологические рассуждения обладают статусом непререкаемой истины, но они достаточно влиятельны для того, чтобы стать, по крайней мере, объектом внимания теологов.

Траектории движения постметафизической и деконструктивистской теологии небезуспешно намечаются уже на протяжении нескольких десятилетий. Среди наиболее влиятельных ориентиров - теологическая этика Э. Левинаса, который предложил мыслить Бога как Того, кто побуждает нас любить Другого [Левинас 1998]. Бог открывается теологу не как «основа бытия», а как условие возможности любви, условие возможности встречи с другим человеком именно как другим, а не как нашим собственным отражением или «двойником». В том же, что и Левинас, феноменологическом русле находится теологическое мышление Ж.-Л. Мариона, который под влиянием поздних работ Ж. Деррида понимает Бога как абсолютный дар, как условие возможности дара вообще [О Даре... 2011]. В свою очередь Ж.-Л. Марион задал эстетический поворот в феноменологической теологии, развитый Дж. Мануссакисом. Последний критически пересмотрел классическое положение феноменологии о том, что Бог как трансцендентное не относится к области данного, а значит не может быть предметом фе- номенологического анализа. Христианская концепция боговоплощения, по мысли Мануссакиса, позволяет преодолеть этот феноменологический запрет и показать, каким образом недоступный Бог монотеистической традиции может быть «дан» в опыте ощущений [Maнуссакис 2014; Христокін 2011].

Источником плодотворных идей современной теологии выступает, как это не парадоксально на первый взгляд, мыслитель-атеист Ж. Деррида. В своих последних трудах он сопрягал атеизм с негативной теологией. Деррида рассматривал атеизм как деликатную форму теологии в ситуации дискредитации традиционного теологического дискурса. После столетий неумолкающих рассуждений о Боге нужен своеобразный интеллектуальный карантин - молчание о Боге или говорение о нем только в форме отрицания. Современная теология не может сказать что-то новое о Боге в положительных утверждениях. Но она как бы предостерегает от слишком поспешных теологических суждений и показывает, какие высказывания о Боге, по крайней мере, сомнительны [Derrida... 1992; Гурко 2001; Сидоров 2009]. Продолжая эту линию, Ж.-Л. Марион интерпретирует философскую критику теологии как идолоборческую практику, расчищающую поле для теологических суждений, свободных от явных или (самое главное) скрытых форм идолатрии [Марион 2009].

Современная социокультурная ситуация дает теологии уникальный шанс. Исчерпание секулярного проекта модерна и постмодернистский плюрализм позволяют ей выйти из исторической резервации и стать полноценным явлением постсекулярного мира. Постсекулярный мир вернул религиозной тематике и теологическому дискурсу утраченную казалось интеллектуальную респектабельность. Левые интеллектуалы, марксисты, атеисты всерьез заговорили в своих трудах о Боге. Религиозные организации возвращают себе право голоса и общественно-политической жизни. Религиозный опыт рассматривается как форма универсального опыта человека. Однако, постсекулярная ситуация предъявляет свои требования и к теологу. Едва ли теолог может претендовать на роль современного теолога, если он не знаком, по крайней мере, с Марксом, Ницше и Фрейдом. Это знакомство для 
современного теолога столь же необходимо, как для христианского богослова эпохи Вселенских соборов было необходимо знакомство с Платоном и Аристотелем.

\section{ПРИМЕЧАНИЯ}

${ }^{1}$ Вместе с тем, подобное понимание богов (Бога) можно обнаружить и в юнгианстве. Следует отметить также, что оно находится в зависимости от феноменологии священного Рудольфа Отто, который понимает божественное, как безгранично превосходящее человека своими свойствами [Отто 2008].

${ }^{2}$ На связь «театра» и «теории» автору статьи указал Д.Е. Скворцов [Скворцов 2015, 24].

${ }^{3}$ Прилагательное «языческие» берется в кавычки для того, чтобы подчеркнуть условность его использования: в действительности «язычество» это конструкт монотеистических полемистов; «язычники» же не чувствовали себя единой группой, как и не всегда поддерживали отчуждение от христиан. Теперь уже не так легко восстановить атмосферу той эпохи. Мы знаем о ней в основном со слов победителей. Разумеется, уже в III веке христианство стало заметным явлением для интеллектуалов Средиземноморского региона, и лидер неоплатоников Порфирий писал труды, направленные против христиан. Однако едва ли можно говорить о некоем «языческом» альянсе, направленном против христиан. Однако в IV веке конфессиональная политика императора Юлиана («Отступника») в каком-то смысле сформировала два противостоящих друг другу лагеря, в одном из которых находились христиане, а в другом - приверженцы «традиционной» для грекоримского мира религиозности, квалифицируемой христианами как «язычество».

${ }^{4}$ Наиболее показательный и даже курьезный пример такого богословского дилетантизма - сапожник Якоб Бёме. Здесь дилетант - это не оценочное понятие, а констатация. Хорошо известно, что многие революционные новации предлагались именно дилетантами, так как профессиональная среда оказывалась чрезмерно косной, инертной.

${ }^{5}$ Подробно феноменологические вызовы и шансы теологии обсуждаются в статье Анны Ямпольской [Ямпольская 2011], а также в беседе Светланы Коначевой и Александра Кырлежева [Коначева, Кырлежев 2020].

\section{СПИСОК ЛИТЕРАТУРЫ}

Александров и др. web-Александров Е., Алферов Ж., Абелев Г., Барков Л., Воробьев А., Гинзбург В.,
Инге-Вечтомов С., Кругляков Э., Садовский М., Черепашук $A$. Открытое письмо Президенту Российской Федерации В.В. Путину [Научнопросветительский журнал «Скепсис»] // http:// scepsis.net/library/id_1346.html.

Аристотель 1976 - Аристотель. Сочинения в четырех томах. Т. 1. М.: Мысль, 1976.

Ведешкин 2014 - Ведешкин М.А. Языческая интеллектуальная элита Восточной Римской империи в V-VI веках // Интеллектуальные традиции в прошлом и настоящем. Вып. 2. М.: Аквилон, 2014. С. 153-191.

Гурко 2001 - Гурко Е. Деконструкция: тексты и интерпретация. Деррида Ж. Оставь это имя (Постскриптум), Как избежать разговора: денегации. Минск: ЭКОНОМПРЕСС, 2001.

Дюркгейм 2018 - Дюркгейм Э. Элементарные формы религиозной жизни. М.: Элементар. формы, 2018.

Коначева, Кырлежев 2020 - Коначева С.А., Кырлежев А.И. Пути постметафизического мышления о Боге // Вопросы теологии. 2020. № 2. С. 177-198.

Коростовцев 2000 - Коростовиев М.А. Религия Древнего Египта. СПб.: Журнал «Нева» : «Летний сад», 2000.

Левинас 1998 - Левинас Э. Время и другой. Гуманизм другого человека. СПб.: Высш. религ.филос. шк., 1998.

Лосев 1988 - Лосев А.Ф. История античной эстетики. Последние века. Кн. 1, 2. М.: Искусство, 1988.

Малиновский 1998 - Малиновский Б. Магия. Наука. Религия. М.: Рефл-бук, 1998.

Мануссакис 2014 - Мануссакис Дж.П. Бог после метафизики. Богословская эстетика. Киев: ДУХ І ЛІТЕРА, 2014.

Марион 2009 - Марион Ж.-Л. Идол и дистанция // Символ. 2009. № 56. С. 5-287.

Марион 2011 - Марион Ж.-Л. Метафизика и феноменология - на смену теологии // Логос. 2011. № 3 (82). С. 124-143.

Митрополит Волоколамский Иларион (Алфеев Г.В.) 2019 - Митрополит Волоколамский Иларион (Алфеев Г.В.). Теология в современной России. К изданию нового журнала // Вопросы теологии. 2019. Т. 1, № 1. С. 3-8. DOI: http:// doi.org/10.21638/spbu28.2019.101.

О Даре... 2011 - О Даре: Дискуссия между Жаком Деррида и Жан-Люком Марионом // Логос. 2011. № 3. С. 144-171.

Отто 2008 - Отто Р. Священное. Об иррациональном в идее божественного и его соотношении с рациональным. СПб.: Изд-во С.-Петерб. ун-та, 2008.

Пигалев 1999 - Пигалев А.И. Антропный принцип: сущность и метаморфозы // Вестник Волгог- 
радского государственного университета. Серия 4, История. Философия. 1999. Вып. 4. C. 60-72.

Пигалев 2001 - Пигалев А.И. Культура как целостность: (Методологические аспекты). Волгоград: Изд-во ВолГУ, 2001.

Пигалев 2004 - Пигалев А.И. Бог и обратная связь в сетевой парадигме Грегори Бейтсона // Вопросы философии. 2004. № 6. С. 148-159.

Платон 1994 - Платон. Собрание сочинений. В 4 т. Т. 3. М.: Мысль, 1994.

Розеншток-Хюсси 2000 - Розеншток-Хюсси О. Избранное: Язык рода человеческого. М.; СПб.: Унив. кн., 2000.

Светлов 2000 - Светлов Р. В. Дамаский Диадох как представитель Афинской школы неоплатонизма // Дамаский Диадох. О первых началах. СПб., 2000. С. 755-828.

Сидоров 2009 - Сидоров А.М. Деконструкция и теология // Вестник Санкт-Петербургского университета. Серия 6, Философия. Культурология. Политология. Право. Международные отношения. 2009. Вып. 3. С. 128-132.

Скворцов 2015 - Сквориов Д.Е. Образное мышление как предмет философско-антропологического анализа: автореф. дис. .... канд. филос. наук. Волгоград, 2015.

Снисаренко 2020 - Снисаренко Ю.А. Теология в международном научно-образовательном пространстве // Вопросы теологии. 2020. Т. 2, № 1. C. 118-135. DOI: http://doi.org/10.21638/ spbu28.2020.108.

Узленар 2011 - Узланер Д. Введение в постсекулярную философию // Логос. 2011. № 3 (82). C. $3-32$.

Фрагменты... 1989 - Фрагменты ранних греческих философов (Часть I). От эпических теокосмогоний до возникновения атомистики. М.: Наука, 1989.

Хабермас 2011 - Хабермас Ю. Между натурализмом и религией. Философские статьи. М.: Весь Мир, 2011.

Хайдеггер 1997 - Хайдеггер M. Тождество и различие. М.: Гнозис : Логос 1997.

Христокін 2011 - Христокін Г. Постмодерний неопатристичний містичний емпіризм Йоана Манузакіса // Sententiae XXIV. № 1. С. 101-109.

Ямпольская 2011 - Ямпольская А. Феноменология как снятие метафизики? // Логос. 2011. № 3 (82). C. 107-123.

Derrida... 1992 - Derrida and Negative Theology. N.Y.: State University of New York Press, 1992.

Rosenstock-Huessy 1958 - Rosenstock-Huessy E. Das Geheimnis der Universität. Stuttgart: W.-Kohlhammer-Verlag, 1958.
Whitteker 1918 - Whitteker Th. The Neo-Platonists. A Study in the History of Helenism. Cambridge: The University Press, 1918.

\section{REFERENCES}

Aleksandrov E., Alferov Zh., Abelev G., Barkov L., Vorob'ev A., Ginzburg V., Inge-Vechtomov S., Kruglyakov E., Sadovskij M., Cherepashchuk A. Public Letter to President of Russia Vladimir Putin. Nauchno-prosvetitelskiy zhurnal «Skepsis». URL: http://scepsis.net/library/id_1346.html.

Aristotle', 1976. Works in 4 vol. Vol. 1. Moscow, Mys1 Publ.

Vedeshkin M.A., 2014. Pagan Intellectual Elite of East Roman Empire in $5^{\text {th }}-6^{\text {th }}$ centuries. Intellektualnye traditsii v proshlom $i$ nastoyashchem. Iss. 2. Moscow, Akvilon, pp. 153-191.

Gurko E., 2001. Deconstruction: Texts and Interpretation. Derrida Zh. Except the Name (Postscript), How to Avoid the Talking: Denegations. Minsk, EKONOMPRESS.

Durkheim E., 2018. Elementary Forms of Religious Life. Moscow, Elementarnye formy Publ.

Konacheva S.A., Kyrlezhev A.I., 2020. The Ways of Post-Metaphysical Thinking of God. Voprosy teologii, no. 2, pp. 177-198.

Korostovcev M.A., 2000. Religion of Ancient Egypt. Saint Petersburg, Zhurnal «Neva»; «Letnij sad».

Levinas E., 1998. Time and Other. The Humanism of Another Human Being. Saint Petersburg, Vysshaya religiozno-filosofskaya shkola.

Losev A.F., 1988. The History of Ancient Esthetics. Last Centuries. Vol. 1, 2. Moscow, Iskusstvo Publ.

Malinowski B., 1998. Magic. Science. Religion. Moscow, Refl-buk Publ.

Manoussakis J., 2014. God After Metaphysics. The Theological Esthetics. Kiev, DUH I LITERA.

Marion J.-L., 2009. The Idol and Distance. Simvol, no. 56, pp. 5-287.

Marion J.-L., 2011. Metaphysics and Phenomenologyin Place of Theology. Logos, no. 3 (82), pp. 124143.

Mitropolit Volokolamskij Ilarion (Alfeev G. V.), 2019. Theology in Contemporary Russia. Toward the publication of new journal. Voprosy teologii, vol. 1, no. 1, pp. 3-8. DOI: http://doi.org/10.21638/ spbu28.2019.101.

The Gift: The Discussion Between J. Derrida and J.-L. Marion, 2011. Logos, no. 3, pp. 144-171.

Otto R., 2008. The Sacred. Of Irrational in the Idea of Godhood in Its Relationship with Rational. Saint Petersburg, Izd-vo S.-Peterb. un-ta.

Pigalev A.I., 1999. The Anthropic Principal: Its Meaning and Metamorphosis. Vestnik Volgogradskogo 
gosudarstvennogo universiteta. Seriya 4, Istoriya. Filosofiya, iss. 4, pp. 60-72.

Pigalev A.I., 2001. Culture as Totality (Methodological aspects). Volgograd, Izd-vo VolGU.

Pigalev A.I., 2004. God and Feedback in the Network Paradigm of Gregory Bateson. Voprosy filosofii, no. 6, pp. 148-159.

Platon, 1994. Works. In 4 vol. Vol. 3. M., Mysl' Publ.

Rosenstock-Huessy O., 2000. The Selected. Language of Human Race. Moscow, Saint Petersburg, Universitetskaya kniga Publ.

Svetlov R.V., 2000. Damascius Diadochus as the Representative of the Athenian Neo-Platonic School. Damascius Diadochus. O pervykh nachalakh. Saint Petersburg, pp. 755-828.

Sidorov A.M., 2009. Deconstruction and theology. Vestnik Sankt-Peterburgskogo universiteta. Seriya 6, Filosofiya. Kulturologiya. Politologiya. Pravo. Mezhdunarodnye otnosheniya, iss. 3, pp. 128-132.

Skvorcov D.E., 2015. Figurative Thinking as the Subject of Philosophical and Anthropological Analysis: avtoref. dis. ... kand. filos. nauk. Volgograd.

Snisarenko Yu.A., 2020. Theology in the international Space of Science and Education. Voprosy teologii, vol. 2, no. 1. DOI: http://doi.org/ 10.21638/spbu28.2020.108.

Uzlaner D., 2011. Introduction in the Post-Secular Philosophy. Logos, no. 3 (82), pp. 3-32.

Fragments of the Early Greek Philosophers. (Part I). From the Epic Theo-Cosmologies to the Beginning of Atomism, 1989. Moscow, Nauka Publ.

Habermas Yu., 2011. Between Naturalism and Religion. Philosophical Papiers. Moscow, Ves Mir Publ.

Heidegger M., 1997. Identity and Difference. Moscow, Gnozis Publ., Logos Publ.

Hristokin G., 2011. Postmodern Neo-Platonic Mystic Empiricism of John Manoussakis. Sententiae $X X I V$, no. 1, pp. 101-109.

Yampol'skaya A., 2011. Phenomenology as the Aufhebung of Metaphysics. Logos, no. 3 (82), pp. 107-123.

Derrida and Negative Theology, 1992. New York, State University of New York Press.

Rosenstock-Huessy E., 1958. Das Geheimnis der Universität. Stuttgart, W.-Kohlhammer-Verlag.

Whitteker Th., 1918. The Neo-Platonists. A Study in the History of Helenism. Cambridge, The University Press.

\section{Information About the Author}

Dmitriy R. Javorskiy, Doctor of Sciences (Philosophy), Professor, Department of Philosophy, Volgograd State University, Prosp. Universitetsky, 100, 400062 Volgograd, Russian Federation, d.r.yavorsky@yandex.ru, https://orcid.org/0000-0002-9198-4847

\section{Информация об авторе}

Дмитрий Ромуальдович Яворский, доктор философских наук, профессор кафедры философии, Волгоградский государственный университет, просп. Университетский, 100, 400062 г. Волгоград, Российская Федерация, d.r.yavorsky@yandex.ru, https://orcid.org/0000-0002-9198-4847 